\title{
The Pragmatist Skepsis as a Social Practice
}

skepticism, Irony and Cultural Politics in Rorty's Philosophy

Olivier Tinland

\section{(2) OpenEdition}

\section{Journals}

Electronic version

URL: http://journals.openedition.org/ejpap/537

DOI: $10.4000 /$ ejpap.537

ISSN: 2036-4091

\section{Publisher}

Associazione Pragma

\section{Electronic reference}

Olivier Tinland, "The Pragmatist Skepsis as a Social Practice», European Journal of Pragmatism and American Philosophy [Online], V-2 | 2013, Online since 24 December 2013, connection on 01 May 2019. URL : http://journals.openedition.org/ejpap/537 ; DOI : 10.4000/ejpap.537

This text was automatically generated on 1 May 2019.

\section{(c) $(1)$}

Author retains copyright and grants the European Journal of Pragmatism and American Philosophy right of first publication with the work simultaneously licensed under a Creative Commons AttributionNonCommercial-NoDerivatives 4.0 International License. 


\title{
The Pragmatist Skepsis as a Social Practice
}

\author{
Skepticism, Irony and Cultural Politics in Rorty's Philosophy
}

\author{
Olivier Tinland
}

1 One of the most underrated problems of philosophy is whether philosophical vocabularies - and thereby the sets of problems articulated in such vocabularies - are perishable products, whether they have a date of expiration written on their back. It is one thing to talk deliberately in an old-fashioned way, using outdated notions for the sake of elegance or nostalgia; it is another to appeal to words or topics one thinks to be perfectly up-to-date, though they turn out, after closer examination, to be no longer valid. Richard Rorty has been one of the main philosophers focusing on that specific - and quite unusual - kind of problem. One of his main Darwinian-Kuhnian ${ }^{1}$ claims is that philosophical (as well as artistic, scientific, political...) vocabularies evolve constantly, going through "revolutionary" phases and more or less massive changes of paradigms, so that one have to be aware of such conceptual (r)evolutions before entering philosophical debates (unlike the "intuitive realists" who seem to believe in the ahistorical and perennial nature of fundamental problems, such as Thomas $\mathrm{Nagel}^{2}$ ). The recurring debate between skepticism and antiskepticism may be one of those old cherished discussions one likes to revive from time to time, speaking in an old-fashioned way about outmoded issues. From this perspective, it is not implausible to see the topic of skepticism as being a dead star, shining in the sky of ideas long after the real star is gone.

2 What I would like to do here is to investigate the meaning and the significance of skepticism in Richard Rorty's philosophy, wondering whether such a dead star continues to shine in Rorty's own private sky of ideas. First, we might notice what appears like a contradiction in the widely-shared interpretation of Rorty's thought: on the one hand, one may be tempted to regard his critique of the classical view of knowledge as a clear expression of skepticism towards the very possibility of achieving an objective theoretical account of reality; on the other hand, it is also well-known that Rorty's deconstruction of modern philosophy as a representationalist, epistemology-centered discipline trying to 
mirror the objective proprieties of nature involves the critical redescription of one of its most fascinating by-products: skepticism. ${ }^{3}$ If one rejects the classical self-conception of the philosophical task, one also has to deny the significance of its negation, i.e. one has to deny the relevance of the skeptical stance. Rorty could then be portrayed paradoxically as a Skeptic who has destroyed the very possibility of skepticism, not only its concrete possibility in everyday practice (like Hume maybe did), but also its theoretical one. Unsurprisingly, Rorty shows absolutely no interest in being involved in further debates between skeptics and antiskeptics:

Representationalists typically think that controversies between idealists and realists were, and controversies between skeptics and antiskeptics are, fruitful and interesting. Antirepresentationalists typically think both sets of controversies pointless. They diagnose both as the results of being held captive by a picture, a picture from which we should by now have wriggled free. (Rorty, 1991a: 2-3)

The relation between pragmatism and skepticism has often been seen as an antagonistic one. ${ }^{4}$ Charles Sanders Peirce, the founding father of pragmatism, wrote several famous papers to deny any relevance to Cartesian skepticism and to oppose to such unnatural doubts the fallibilistic pursuit of truth. Such an antiskeptical stance is to be found almost everywhere, among the classical as well as the most recent advocates of pragmatism, for instance in William James and Hilary Putnam's philosophies. However, Rorty's case seems to be particularly difficult to decide: is he to be considered an opponent or an accomplice of skepticism? On the one hand, in his first book Philosophy and the Mirror of Nature, Rorty is clearly undertaking to overcome modern skepticism by linking it to a set of theoretical commitments which give rise, at the beginning of the 17th century, to "epistemology as first philosophy." Thus understood, modern skepticism should fade away with the theoretical context it belongs to, in favor of a social pragmatist and antirepresentationalist view of philosophy. On the other hand, in his second major book Contingency, Irony and Solidarity, Rorty sketches a new intellectual figure, the "liberal ironist," who looks very much like a Humean "mitigated" skeptic, continuingly doubting the validity of her own beliefs and the relevance of her "final vocabularies," even including reflective doubts about her own doubts. This new figure seems to create a tension, if not a contradiction, between Rorty's alleged commitment to pragmatism and such an attraction to one of the main illustrations of modern skepticism. What I want to do in this paper is to provide a brief presentation of this tension between pragmatism and skepticism in Rorty's philosophy. I shall then try to show that there is in fact no contradiction between these two commitments: in spite of appearances, the Rortyan ironist is not a regression to a pre-pragmatic stance, it is rather a "conceptual character" of sorts, playing a role in a wider philosophical context in which skepticism is to be overcome by its integration into a social pragmatist view. I shall finally try to show that Rorty's complex relation to skepticism may be a good way to consider a new type of skepsis, beyond the rigid (and quite unproductive) opposition of pragmatism and skepticism, namely a pragmatic skepsis emancipated from the perishable vocabulary of modern skepticism, actively engaged in social and political debates involving rival descriptions of human culture.

My claim will be the following: in his attempt to connect skepticism to the emergence of modern epistemology, Rorty seems to reduce skepticism to its theoretical side, failing to provide a complete account of this philosophical option. We might then be tempted to see the practical side of skepticism as the "return of the repressed" in Rorty's later philosophy, especially when he depicts the controversial figure of the liberal ironist. 
However, I would like to show that such a view is misleading, since it fails to take account of Rorty's redefinition of the philosophical discourse under the bewildering label of "cultural politics."

\section{Representationalism and Skepticism}

5 In his book Philosophy and the Mirror of Nature, and in particular in the second part of the book named "Mirroring," Rorty aims at uncovering a quite unnoticed link between a certain conception of philosophy as "epistemology" (or Erkenntnistheorie) and the rise of modern skepticism. What he has in mind (to use Michael Williams labels) isn't a "therapeutic diagnosis" which sees skepticism as a pseudo-problem which has to be dissolved, but rather a "theoretical diagnosis" which considers modern skepticism - "the specifically 'Cartesian' form of skepticism which invokes the 'veil of ideas' as a justification for a skeptical attitude" - to be a set of genuine problems depending on a specific theoretical context that has to be questioned. I won't examine Rorty's argument in detail but will rather sum up the core ideas of his historical reconstruction of modern epistemology in order to make explicit some problems it involves regarding skepticism.

Let me first give a concise overview on Rorty's genealogical narrative about the emergence of epistemology as first philosophy: ${ }^{6}$ since the 17th century, people have thought of knowledge as a "problem" about which they ought to have a "theory" because they saw knowledge as an "assemblage of representations," or as a set of thoughts mirroring (more or less accurately) the objective reality of nature. Descartes and Locke conceive of the mind as the new ground of philosophy. This field of investigation is "prior" to the other ones in at least two respects: a) since we can perceive the external world only through the mind (sensations, ideas), we have to know the mind in order to know the world; b) unlike our access to the external world, the access to the mind is direct, immediate, providing a genuine "certainty" rather than fallible "opinion." Thus understood, the mind becomes the subject matter of a distinct science - the "science of man" as opposed to "natural philosophy" - which deals with the outer world. Focusing on "what we can know by studying how our mind worked" gives birth to "epistemology": this self-reflective science appears first as empiricism (Locke) but soon evolves into a non-empirical science, thus avoiding the risk of losing the strict demarcation between absolute certainty and mere opinion. Kant is the one who succeeds in turning the empiricist conception of epistemology into a non-empirical (a priori) task by internalizing the laws of nature as grounded in the "constituting transcendental ego." Epistemology becomes then a "foundational science" capable of discovering the essential features of human knowledge prior to any investigation of the external world. After the Kantian revolution, historians of philosophy project its core question "how is our knowledge possible?" back onto pre-Kantian philosophy, not only onto the thinkers of the 17th and 18 th centuries, but onto the ancients as well. Such a retrospective illusion makes possible the unification of philosophy under the label of "epistemology." The picture of "epistemology and metaphysics" as the center of philosophy is the outcome of the representationalist view of the relation between mind and world: now the mind is seen as a set of ideas mirroring the world which makes possible the identification of philosophy with the theoretical elucidation of such a relation.

7 The core idea of Rorty's diagnosis is the following: contrary to other recent interpretations of skepticism (such as that proposed by Barry Stroud in The Significance of 
philosophical Scepticism ${ }^{7}$ ), Rorty thinks that the skeptical stance does not "appeal to something deep in our nature" but is a mere by-product of the representationalist conception of philosophy as epistemology. According to this view, skepticism is not to be seen as independent of the theoretical framework of epistemology, since its main concern is the possibility to bridge the gap between mind and world or to rip the "veil of ideas" that keep us away from the "real" world:

The veil-of-ideas epistemology which took over philosophy in the seventeenth century transformed skepticism from an academic curiosity (Pyrrhonian skepticism) and a concrete and local theological issue (the authority of the church versus the individual reader of Scripture) into a cultural tradition. It did so by giving rise to a new philosophical genre - the system which brings subject and object together again. This reconciliation has been the goal of philosophical thought ever since. (Rorty, 1979: 113)

The skeptical threat of "losing the world" is thus dependent upon the modern picture of the mind as an "inner" substance trying to reach an "outer" reality. ${ }^{8}$ If one gives up the framework of what Rorty names the "glassy essence" of mind (for instance in favor of a pragmatic or "behavioristic" conception of language and beliefs), skepticism vanishes instantly like a theoretical ghost. In other words, skepticism is not a real and prephilosophical problem one would have to solve, but rather a philosophical delusion one ought to dispel: if one manages to resist the strong attraction of the representationalist picture of mind and its close ally, the conception of philosophy as an internal and a priori investigation of the mind, then the problem of skepticism simply fades away.

of course, it is obvious that such a claim about modern philosophy in general and skepticism in particular is highly controversial. Many objections might be mentioned here, but I will focus on one that seems to me most relevant to my topic: Rorty's emphasis on modern skepticism prevents him from connect early modern skepticism to ancient skepticism and hence to notice the persistence of a practical concern in both cases. Such a connection would allow us to see that skepticism has as much to do with practice as it has to do with theory: ${ }^{9}$ Pyrrho's case, for instance, is very interesting because his skeptical stance has much more to do with practical issues (how to free the human soul from worries and reach the spiritual autarkeia...) than theoretical ones. Of course, Rorty is fully aware of the shift of meaning between ancient and modern skepticism; in PMN, he writes:

Whereas skepticism in the ancient world had been a matter of a moral attitude, a style of life, a reaction to the pretensions of the intellectual fashions of the day, skepticism in the manner of Descartes's First Meditations was a perfectly definite, precise, 'professional' question: How do we know that anything which is mental represents anything which is not mental? How do we know whether what the Eye of the Mind sees is a mirror (even a distorted mirror- an enchanted glass) or a veil? (Rorty, 1979: 46)

10 Nevertheless, such a clear awareness of the contrast between ancient and modern skepticism doesn't prevent Rorty from neglecting the practical side of modern skepticism. Too eager to portray modern philosophy as solely focused on epistemological problems, Rorty fails to recognize the existence of an essential link between theory and practice in such modern philosophy, ignoring major skeptical figures such as Montaigne or Pierre Bayle, as well as neglecting the practical (moral, religious, political) side of Descartes and Locke's focus on the mind. Rorty is thus unable to provide a convincing account of modern skepticism's motivation. 
11 Here, we can see one of the major contradictions of the young Rorty's conception of philosophy: his critique of modern philosophy shares the same defect as its subject (what he calls "a sort of prolegomenon to a history of epistemology-centered philosophy as an episode in the history of European culture" (Rorty, 1979: 390), namely too narrow a focus on theoretical philosophy at the expense of the practical philosophy. It is quite ironic that Rorty, at the same time as he seeks to show, in a pragmatist vein, that philosophy has much more to do with practical issues than it appears, also fails at the same time to deal with the complex connection between the skepticisms theoretical and moral sides in his own historical narrative. In his reply to Michael Williams, he recognizes such a limit of his inquiry but doesn't seem to be fully aware of its wider philosophical consequences:

Like too many other contemporary writers on the history of philosophy, I thought that it was enough to grasp interaction of scientific and philosophical change. I did not see the need to bring in the changes in moral and political thought which resulted from the interaction of scientific and religious changes with one another. (...) The traditional insistence that 'metaphysics and epistemology' make up the 'core' of philosophy has given us histories of philosophy which marginalize the history of ethics. (Rorty, 2000: 214 and 218, n. 4).

This one-sided focus on the theoretical side of skepticism could have serious consequences, not only from the perspective of the history of philosophy, but with regard to Rorty's later philosophy. Failing to recognize the importance of practical concerns in modern skepticism seems to undermine Rorty's diagnosis of the "death of epistemology" and the account of skepticism that goes with it. This is the issue I would like to address in the next section by examining Rorty's successor figure to skepticism: liberal irony.

\section{Irony and Skepticism}

13 Having finished reading Philosophy and the Mirror of Nature, one might be convinced that skepticism is indeed a perishable intellectual product that ought not to be part of the philosophical conversation anymore. This may be thought to be so because skepticism shares the same destiny as the flawed philosophical framework upon which it has been living as an intellectual parasite: modern epistemology seen as a foundational, mentalist, representationalist undertaking. However, this impression quickly fades as once one turns Rorty's second major book, Contingency, Irony and Solidarity. There from the very beginning Rorty draws the reader's attention to what might be seen as a new and more sophisticated figure of the skeptic: the liberal ironist.

Such a new and more comprehensive figure might also be called the "post-Nietzschean skeptic" and can be seen as the result of the crisis of the modern project of epistemology: if the project of grounding knowledge of nature on the understanding of a universal human nature falls apart, then representationalist skepticism has to be abandoned in favor of a new kind of skepticism, a skepticism focused not on our relation to the external world, but on the very core of epistemology as first philosophy, namely the ideal of a common and permanent human nature transcending every social and historical context and grounding the possibility of genuine knowledge. The rise of this new skepticism first gives birth to anti-universalist and anti-social skeptics - what a Rortyan may call "unreflective" skeptics - which reject social solidarity after having merely replaced the metaphysical ideal of a universal human nature by a pessimistic account of what lies beneath collective life: 
Skeptics like Nietzsche have urged that metaphysics and theology are transparent attempts to make altruism look more reasonable than it is. Yet such skeptics typically have their own theories of human nature. They, too, claim that there is something common to all human beings - for example, the will to power, or libidinal impulses. Their point is that at the 'deepest' level of the self there is no sense of human solidarity, that this sense is a 'mere' artifact of human socialization. So such skeptics become antisocial. They turn their backs on the very idea of a community larger than a tiny circle of initiates. (Rorty, 1989: xiii) the connection between the individual quest for fulfillment and the collective task of creating solidarity: on the one hand there are the metaphysicians who tend to reduce the individual task to a mere epiphenomena of a universal human nature, whereas on the other hand there are the post-nietzschean skeptics who tend to reduce social life to a collective lie based on false metaphysics that must be overcome by individual selfcreation. Both sides tend to underestimate the distinction between the private and the public and to extend their universalist or idiosyncratic program to both spheres, each falling into fatal contradictions: while the metaphysicians fail to turn their universalist political agenda into a rational justification, the skeptics fail to export their antiuniversalist doubts in the public life without threatening to jeopardize the very basis of the society which makes possible freedom of thought. In opposition to both, Rorty thinks that we must "drop the demand for a theory which unifies the public and private, and [be] content to treat the demands of self-creation and of human solidarity as equally valid, yet forever incommensurable" (Rorty, 1989: xv). The new skeptical figure which exemplifies such a biperspectival view is embodied by what Rorty calls the "liberal ironist," a skeptic who, like the Humean mitigated skeptic, is skeptical about her own skepticism, about the public legitimacy of her own private motives, about the universal scope of her own personal doubts:

I use "ironist" to name the sort of person who faces up to the contingency of his or her own most central beliefs and desires - someone sufficiently historicist and nominalist to have abandoned the idea that those central beliefs and desires refer back to something beyond the reach of time and chance. (Rorty, 1989: xv)

Here we can see that Rorty forges a far more interesting skeptical figure than in Philosophy and the Mirror of Nature: the ironist is not someone detached from any practical context, who relies on some kind of naïve epistemological realism (to use Michael Williams' words again) but someone who is fully aware of the contingency of her own stance, of the contingency of skepticism itself, which is nothing more than a "final vocabulary" among other vocabularies. Rorty gives us this striking portrayal of the ironist:

I shall define an "ironist" as someone who fulfills three conditions: (1) She has radical and continuing doubts about the final vocabulary she currently uses, because she has been impressed by other vocabularies, vocabularies taken as final 
by people or books she has encountered; (2) she realizes that argument phrased in her present vocabulary can neither underwrite nor dissolve these doubts; (3) insofar as she philosophizes about her situation, she does not think that her vocabulary is closer to reality than others, that it is in touch with a power not herself. Ironists who are inclined to philosophize see the choice between vocabularies as made neither within a neutral and universal metavocabulary nor by an attempt to fight one's way past appearances to the real, but simply by playing the new off against the old. (Ibid.: 73) comprehensive than the former one, which was exclusively focused on the theoretical problem of epistemology. However, one might wonder whether Rorty's successor figure of skepticism is consistent with his deep pragmatist commitments. Here we can refer usefully to Michael Williams' objections in his article "Rorty on Knowledge and truth" (Williams, 2003): one has to distinguish between two forms of skepticism, a mild one which is compatible with pragmatic commitments, and a radical one which is incompatible with them. The "mild form of skepticism," called "fallibilism," amounts to the thought that our beliefs are not absolutely certain and may therefore be subject to revision. Such a form a skepticism is perfectly compatible with pragmatism, as we can see in Peirce or Dewey's conception of inquiry. As a pragmatist, Rorty should be committed only to fallibilism: it may then come as a surprise to see him espouse views which seem very close to a far more radical form of skepticism. The ironist, claims Rorty, has continuous doubts about her final vocabularies, which means that she is aware of the impossibility of justifying her ultimate commitments in a non-circular way, i.e. without having to face the challenge of Agrippan skepticism. Such a worry seems to be at odds with Rorty's pragmatist holistic Davidsonian view of beliefs: having beliefs implies mastering a language, which implies having mostly right beliefs about the world. Rorty's conception of irony seems thus to be a regression to a pre-pragmatic view of beliefs which threatens to reactivate outdated those aporias linked to a foundationalist conception of truth. From a consistent pragmatist point of view, being aware of the contingency of our vocabularies shouldn't lead to irony, but to a mere fallibilistic account of the evolution of knowledge, for instance the one we find in Peirce, Dewey or even in the explicitly pragmatist texts of Rorty.

So depicted, Rorty's further conception of skepticism seems to be as unsatisfying as the former one. However, this way of putting Rorty's account seems both unfair and inaccurate. Indeed, as one can easily see, when Rorty speaks of irony, he never uses the word "skeptic" and for good reasons, as I will now argue. In an important footnote of Unnatural Doubts, Michael Williams suggests that such an omission shouldn't prevent the reader to replace one word with another: "Though Rorty prefers 'irony' to 'scepticism', taking himself to have moved beyond all traditional epistemological options, the true 
irony may be that Rorty's ironist is everyone else's sceptic."10 What I would like to show by way of conclusion is that such an equivalence, though tempting, is misleading, missing, as it does, Rorty's point about the status of philosophical skepsis.

\section{Cultural Politics and Skepticism}

21 It is worth noting that even in his last works Rorty continues to view the skeptic as an anachronistic figure that has to be overcome: "a culture in which we no longer took the skeptic's question about whether we are getting nearer to truth would be better than the one in which we ask the philosophy professors to assure us that we are indeed doing so." ${ }^{11}$ Such a continued emphasis on the pointlessness of philosophical skepticism may shed a new light on the figure of the liberal ironist previously sketched in Contingency, Irony, and Solidarity: instead of seeing the liberal ironist as a mere return of the repressed practical side of skepticism, this figure may in fact look more like a transitional figure towards a redefinition of philosophy as a form of social practice, one that is moreover fully emancipated from the skeptic/antiskeptic debate. Such a figure is given an explicitly practical gloss in Rorty's last works in the form of the phrase "philosophy as cultural politics." The phrase is defined by Rorty as a philosophical practice focusing on the shifts of vocabularies in cultural history, allowing to help changing the way we use words or "getting rid of whole topics of discourse." 12

Such a restatement of the philosophical task takes the metaphilosophical movement already at work in the shift from modern skepticism to liberal irony to a higher level of self-reflection: whereas the ironist, having learned from the failure of modern epistemology, is fully aware of the contingency of her own final commitments, including her own doubts about such commitments, the cultural politician is fully aware that the ironist is just another role (or a dramatized conceptual device) she has created among many possibilities, fulfilling a definite function inside a definite philosophical agenda. Such a device is an "incarnated vocabulary" which helps Rorty to rid philosophy of the boring drama that is philosophical skepticism: "Interventions in cultural politics have sometimes taken the form of proposals for new roles that men and women might play: the ascetic, the prophet, the dispassionate seeker after truth, the good citizen, the aesthete, the revolutionary." ${ }^{13}$ Understood from the metaphilosophical point of view of the cultural politician, the liberal ironist is not to be mistaken for a real figure (she is a "utopia," says Rorty), any less than the 17th century skeptic really existed: both are transitory figures depending on the shifts of vocabularies, i. e. on the shifts of the tools allowing us to deal with the new experiences and challenges we have to face in our natural and social environment.

According to Rorty, cultural politics is a new definition of philosophy and it is at the same time a way of understanding how new meanings, including new definitions of philosophy, might eventually become commonsensical: "I want to argue that cultural politics should replace ontology, and also that whether it should or not is itself a matter of cultural politics. ${ }^{14}$ Following the post-Sellarsian path of Robert Brandom, ${ }^{15}$ Rorty claims that the old metaphysical questions giving birth to the various forms of skepticism, in order to be properly assessed, have to be placed inside the social context of intersubjective justification: "All attempts to name an authority which is superior to that of society are disguised moves in the game of cultural politics." ${ }^{16}$ Philosophy is therefore at the same time the subject and the object of cultural politics: its new identity is itself an element in 
the process of changing vocabularies, but this process is not meant to get closer to objective truth or "real" morality. Philosophy is rather the way to face new experiences and integrate them into the evolving network of our existing beliefs.

Again, the liberal ironist isn't a mere problematic reminiscence of practical skepticism, as it first seems to be, but rather, on the contrary, a step on the path leading to a real emancipation from the classical problems of skepticism. Like every concept, it is a tool designed for a special and limited task, i.e. getting rid of the philosophical (Platonic) temptation to unify the individual and the universal, or to rephrase it in the liberal vocabulary (which is just one useful vocabulary among many others), to unify the "private" and the "public." It is therefore a mistake to see the private/public distinction (and to criticize it) as a naïve return to a metaphysical dualism which is inconsistent with Rorty's pragmatist - and anti-dualist - commitments. ${ }^{17}$ Liberal ironism is an antifoundationalist conceptual tool ${ }^{18}$ and, as such, it is not to be reified as Rorty's personal final stance: just as Philosophy and the Mirror of Nature was an attempt at providing new redescriptive tools of Philosophy's status and task, Contingency, Irony, and Solidarity is an attempt at creating a redescriptive utopia about the relation between philosophy and politics. What has been hastily described as a "Humean turn"19 looks rather, after closer examination, like a pragmatist redescription of the existence of philosophy in a liberal society. As such, it doesn't contradict the pragmatist commitment to fallibilism, but we have to understand that fallibilism here is about vocabularies, not theories. Liberal irony may then be described as a revisable conceptual tool (fallibilism) allowing us to use post-nietzschean skepticism (vocabulary) as a means to improve our understanding of the contemporary political predicament of philosophy (experience). Put differently, though Rorty doesn't see skepticism as a relevant philosophical stance per se, he claims that ironic skepsis may play a useful role in the social practice of "cultural politics."

Similarly, the "prophetic feminist" 20 providing new words and new linguistic uses for alternate redescriptions of the condition of women is just another transitional role allowing Rorty to get rid of an old vocabulary (abstract universalist egalitarianism) in favor of a new one (historicist anti-essentialist feminism). Such a prophetic feminism is no longer mere ironism but has learned from the philosophical and political consequences of the ironic stance. ${ }^{21}$ Whereas the ironist was still negatively affected by the impossibility of reaching an objective truth or an ultimate justification (hence taking the contingency of vocabularies for a sign of the precariousness of such vocabularies), the feminist prophet provides "creative misuses of language" 22 in order to turn the social condition of women toward a utopian state of mind, instead of looking for a "true" essence of the "eternal woman" and unmasking the lies and the illusions covering such a hidden truth. In distinction to the ironist, the prophetic feminist isn't influenced by some kind of nostalgia for a lost truth; she is not even some kind of sophisticated self-reflective skeptic captivated by her sharp sense of contingency, just a mature pragmatist thinker who simply doesn't care about skepticism (seen as a permanent philosophical problem) anymore. The quest for universality has been replaced by the sense of hope, the sense of an open future, of a still unpredictable evolution of vocabularies allowing people to deal actively with the interests of the present time.

26 The cultural politician is neither a Cartesian inner mind desperately trying to reach the outer world beyond the veil of her ideas, nor is she a mere ironist trying to stay aware of the contingency of her own beliefs in order to adapt them to the anti-foundationalist 
climate of liberal life: she is rather a conceptual dramatist with a fallibilistic awareness of the contingency of all possible redescriptions (including the ones using conceptual tools such as modern skepticism or liberal ironism). She has emancipated her skepsis from its reified and transitory personifications (Pyrrhonian skeptic, Humean skeptic, liberal ironist) and from the now anachronistic concerns of the outdated intellectual fashion once termed skepticism. It is a mistake to regard Rorty's philosophy as a problematic revival of the Humean outlook, since it is now clear that philosophy as cultural politics implies that every intellectual outlook (including the Humean one) is a potential philosophical tool designed for specific tasks. From a pragmatist point of view, skepticism is neither a permanent challenge to be taken up, nor the fatal predicament of modern humanity, but rather a set of roles which may prove more or less useful in the evolving game of cultural politics. This is what Rorty's relation to skepticism is really about: beyond the simplistic opposition between anti-skepticism (including classical pragmatism) and skepticism, it is necessary to make place for a pragmatic skepsis which constitutes the social practice of philosophy, i.e. the understanding of the permanent shifts of the vocabularies we use to describe our culture, including the one allowing us to define what philosophy's relation to skepticism is really about.

\section{BIBLIOGRAPHY}

BRANDOM R. B. ed., (2000), Rorty and his Critics, Malden, Blackwell.

FRASER N, (1990), "Solidarity or Singularity? Richard Rorty between Romanticism and Technocracy," in Malachowski (1990).

GUIGNON Ch. \& D. R. HILEY (eds.), (2003), Richard Rorty, Cambridge, Cambridge University Press. HABERMAS J., (2003), Truth and Justification, transl. B. Fultner, Cambridge, The MIT Press.

HADOT P., (1995), Qu'est-ce que la philosophie antique ?, Paris, Gallimard.

MALACHOWSKI A. ed., (1990), Reading Rorty, Cambridge, Basil Blackwell.

RORTY R., (1979), Philosophy and the Mirror of Nature, Princeton, Princeton University Press.

RORTY R., (1982), Consequences of Pragmatism, Minneapolis, University of Minnesota Press.

RORTY R., (1989), Contingency, Irony, and Solidarity, Cambridge, Cambridge University Press.

RORTY R., (1991a), Objectivity, Relativism, and Truth, Cambridge, Cambridge University Press.

RORTY R., (1991b), Essays on Heidegger and Others, Cambridge, Cambridge University Press.

RORTY R., (1992), The Linguistic Turn, Chicago, University of Chicago Press.

RORTY R., (1998), Truth and Progress. Philosophical Papers Volume 3, Cambridge, Cambridge University Press.

RORTY R., (1999), Philosophy and Social Hope, New York, Penguin Books.

RORTY R., (2000), “Replies to Williams,” in Brandom 2000. 
RORTY R., (2006), Take Care of Freedom and Truth will take care of Itself, Stanford, Stanford University Press.

RORTY R., (2007), Philosophy as Cultural Politics, Cambridge, Cambridge University Press.

RORTY R., (2008), Philosophy and the Mirror of Nature. 30th Anniversary Edition, Princeton, Princeton University Press.

TIERCELIN C., (2005), Le doute en question. Parades pragmatistes au défi sceptique, Paris, Éditions de l'Éclat.

TOPPER K., (1995), "Richard Rorty, Liberalism and the Politics of Redescription," The American Political Science Review 89, 4, 954-965.

WELSCH W. \& K. UREWIG (eds.), (2003), Das Interesse des Denkens: Hegel aus heutiger Sicht, München, Fink Verlag.

WILliAMS M., (1995), Unnatural Doubts, 2nd edition, Princeton, Princeton University Press.

Williams M., (2000), “Epistemology and the Mirror of Nature," in Brandom 2000.

WILLIAMS M., (2003), "Rorty on Knowledge and Truth," in Welsch \& Urewig 2003.

\section{NOTES}

1. On Rorty's use of Kuhn in a Darwinian pragmatist view of human culture, see Rorty (1979: 322-333) and Rorty (1999, ch. 12).

2. On the critique of "intuitive realism," see Rorty (1982: XXIX-XXXVII).

3. We find a clear diagnosis on "Rorty's skepticism" in Michael Williams' 30th anniversary introduction of Philosophy and the Mirror of Nature: "To his critics, Rorty is a skeptic, a relativist, an irrationalist, and a nihilist. He is none of those things. Rorty is not an epistemological skeptic but rather a skeptic about epistemology. A philosophical skeptic holds, or pretends to hold, that any view is as good as any other. Rorty doesn't think this for a moment. Rorty's view is that skepticism (along with relativism, etc.) is the dark side of epistemology. Epistemology aims at a wholesale justification of our beliefs about the world (with a resultant downgrading of beliefs that resist appropriate grounding). Accordingly, skepticism is where you end up if you think that epistemology ought to work but doesn't. What leads to skepticism is not inadequate epistemology but the very idea that knowledge, justification, and truth are objects of theory." (Rorty, 2009: xxvii).

4. See Tiercelin (2005).

5. Rorty (1979: 94 n. 8).

6. This short presentation owes much to Michael Williams' crystal-clear sketch of Rorty's argument in Williams (2000).

7. Rorty's critique of Stroud's understanding of skepticism is to be found in "Antiskeptical Weapons: Michael Williams versus Donald Davidson" (Rorty, 1998: 153-156).

8. For a convincing sketch of modern « mentalism », see Habermas (2003: 177-180).

9. A presentation focused on the practical side of Pyrrhonism is provided by Hadot (1995: 174-177).

10. Williams (1995: 363, n. 38).

11. Rorty (1998: 6).

12. Rorty (2007: 3).

13. Rorty (ibid.: ix-x).

14. Rorty (ibid.: 5). 
15. On the decisive influence of Brandom on Rorty, see "Robert Brandom on Social Practices and Representations" in Rorty (1998: 122-137), "Cultural Politics and the Existence of God" in Rorty (2007: 3-26) and "Some American Uses of Hegel," in Welsch W. \& Urewig K. (2003).

16. Rorty (2007: 8).

17. In other words, it is misleading to view Rorty's "partition position" as an inconsistent attempt to create a real partition between the private and the public life of individuals (see Fraser, 1990, and Topper, 1995: 961), which would obviously contradict Rorty's own strive to go beyond abstract dualisms through perpetual redescriptions of human culture. In a recent interview, Rorty clearly dismiss this objection, claiming the private/public dichotomy to be a mere matter of vocabularies: "I don't think private beliefs can be fenced off from the public sphere; they leak through, so to speak, and influence the way one behaves toward people. What I had in mind in making the distinction was this: the language of citizenship, of public responsibility, of participation in the affairs of the state, is not going to be an original, selfcreated language." (Rorty, 2006: 50).

18. See Rorty (2006) "Ironism, in this context, means something close to antifoundationalism."

19. Williams (2003: 74). Williams is right to claim that "the neo-Humean outlook involves finding a kind of truth in skepticism. As a pragmatist, Rorty should never claim to find any such thing" (Williams, 2003: 75). He is wrong to think that Rorty does find any truth in skepticism.

20. See "Feminism and Pragmatism" in Rorty (1998: 202-227).

21. To use Nietzschean terms, ironism may be regarded as a pragmatized form of "passive nihilism," whereas prophetic feminism looks more like a form of "active nihilism."

22. Rorty (1998: 204): "One way to change instinctive emotional reactions is to provide new language that will facilitate new reactions. By 'new language' I mean not just new words but also creative misuses of languages - familiar words used in ways that initially sound crazy. Something traditionally regarded as a moral abomination can become an object of general satisfaction, or conversely, as a result of the increased popularity of an alternate description of what is happening."

\section{ABSTRACTS}

In this paper, I address the issue of the consistency of Richard Rorty's multi-layered approach of skepticism, examining three successive steps of this approach: the genealogical critique of theoretical skepticism in Philosophy and the Mirror of Nature, the surprising revival of a skeptical outlook in Contingency, Irony, and Solidarity and the promising sketch of a pragmatist skepsis emancipated from skepticism in the last works dedicated to the restatement of philosophy as "cultural politics." According to some critical readers of Rorty, there is a tension, if not a contradiction, between Rorty's early dismissal of the skeptical stance in the name of pragmatism and the return of a "neo-Humean" stance in his political writings of the 1980's. The aim of this paper is to show that there is no such contradiction between these two orientations, provided one keeps in mind that according to Rorty, philosophy is about creating, strengthening and undermining various descriptions of human culture. Rorty's pragmatist redescriptions include "conceptual characters" which have to be regarded as philosophical tools fulfilling specific tasks: from this perspective, the liberal ironist is not to be considered as the final word of Rorty on political philosophy, but rather as a transitory figure which allows the author of Contingency, Irony, and Solidarity to address the specific problem of the relation between philosophy and 
politics in a liberal (anti-foundational) society. Therefore, liberal ironism is not a naive commitment to skepticism which is inconsistent with the fallibilistic claims of pragmatism: the best way of understanding it is to view it from the perspective of Rorty's last works, i.e. from the perspective of "cultural politics," and to compare it to other philosophical figures fulfilling different tasks, such as the "prophetic feminist."

\section{AUTHOR}

\section{OLIVIER TINLAND}

University Paul Valéry

olivier.tinland[at]univ-montp3.fr 